\title{
The study of the effectiveness of coagulants and white sludge in the process of dephosphotation of municipal wastewater
}

\author{
Tamara Gorbacheva ${ }^{1}$, Dmitriy Mayorov, 2,*, Yuri Velyaev³, and Yar Zar Htun ${ }^{4}$ \\ ${ }^{1}$ Institute of North Industrial Ecology Problems - Subdivision of the Federal Research Centre "Kola \\ Science Centre of the Russian Academy of Sciences”, 184209, Akademgorodok, 14a, Apatity, \\ Murmansk region, Russia \\ ${ }^{2}$ Tananaev Institute of Chemistry - Subdivision of the Federal Research Centre "Kola Science Centre \\ of the Russian Academy of Sciences”, 184209, Akademgorodok, 26a, Apatity, Murmansk region, \\ Russia \\ ${ }^{3}$ Sevastopol State University, 299053, Universitetskaya St., 33, Sevastopol, Russia \\ ${ }^{4}$ University of Mandalay, Department of Chemistry, 05032, 73rd Street, Mandalay, Myanmar
}

\begin{abstract}
The results of the test coagulation of clarified wastewater of urban sewage facilities are presented in this work. A dose of aluminum and iron-containing coagulants in terms of metal oxide $\left(\mathrm{Me}_{2} \mathrm{O}_{3}\right)$ was used as a parameter for comparison of the efficiency of reagent removal of phosphorus from wastewater. It was shown that the uses of any of the selected coagulants make it possible to bring the degree of purification of municipal effluents to the requirements of fishery co-op permissible exposure limit at the stage of simultaneous subsidence, while the best efficiency results are obtained for an aluminum oxychloride coagulant.
\end{abstract}

\section{Introduction}

The main sewage receivers of water and sewage utilities (WSU) of the Russian Federation (Vodokanalov) are internal reservoirs and small watercourses. One of the results noted that decreasing the buffer capacity of internal reservoirs is because of their eutrophication, due to the excess supply of biogenic elements - nitrogen and phosphorus with industrial and municipal effluents [1]. Phosphorus is still considered as a key biogenic element that controls the process of lakes eutrophication, although the N-P control paradigm gradually replaces the phosphorus paradigm [2].

The majority construction of sewage treatment plant (STP) in the Russian Federation with a capacity of 20-50 thousand $\mathrm{m}^{3}$ per day took place in the 70 s of the last century. During this period, the main purpose of municipal effluent cleaning was to remove organic compounds and suspended substances. Removal of some biogenic elements occurred simultaneously - as a result of the microbiological activity of a wide spectrum of action and co-precipitation with suspended substances during settling in primary and secondary settling tanks. The limited capabilities of existing facilities for the treatment of municipal

\footnotetext{
* Corresponding author: d.maiorov@ksc.ru
} 
wastewater from biogenic elements using outdated technologies are represented in Table 1. It should be emphasized that these technologies continue to be applied to the Russian sewage treatment facilities in the present days [3].

As can be seen from data in Table 1, the best indicators of total phosphorus removal were achieved using chemical-mechanical wastewater treatment with chemical reagents.

Table 1. Cleaning performance indicators [4].

\begin{tabular}{|c|c|c|c|c|}
\hline \multirow{2}{*}{ Technical process } & \multicolumn{4}{|c|}{ Treatment efficiency } \\
\cline { 2 - 5 } & BOD5 & $\begin{array}{c}\text { Total suspended } \\
\text { solids }\end{array}$ & $\begin{array}{c}\text { Total } \\
\text { nitrogen }\end{array}$ & $\begin{array}{c}\text { Total dissolved } \\
\text { phosphorus }\end{array}$ \\
\hline Primary treatment & 30 & 60 & 15 & 15 \\
\hline Mechanicochemical purification & $55-70$ & $80-90$ & $25-30$ & $75-90$ \\
\hline Customary biological treatment & 90 & 90 & 30 & 30 \\
\hline
\end{tabular}

There are several traditional technological schemes for the reagent removal of phosphorus are used at wastewater treatment facilities in the Russian Federation: predeposition (addition of reagent before primary settling), simultaneous deposition (addition of reagent to the channel of clarified aeration tank water), post-deposition (addition of reagent after secondary settling tanks). A simultaneous deposition is the simplest technique requiring medium doses of coagulants [5]. Since 2019, the Russian Federation was provided large scale technical re-equipment of water and sewage facilities with sewage treatment facilities with a capacity of more than 20 thousand $\mathrm{m}^{3}$ per day based on the best achievements [6].

This paper presents the results of coagulation test of clarified wastewater of sewage treatment facility JSC «Apatityvodokanal» (Apatity city, Murmansk Oblast) by test coagulation method. Solutions of iron (III) sulfate, aluminum sulfate, aluminum-silicate coagulant (ASC), oxysulfate, and aluminum oxychloride were traditionally used in water purification processes as coagulants [11-22].

Additionally, as a sorbent of phosphate ion it was tested white mud (WM), obtained by neutralizing aluminate solutions of alumina production [7]. Initially, white mud was used as a sorbent to remove fluorine from wastewater [8]. In the subsequent the scope of the WM application was significantly expanded and, on its basis, methods for the production of a sorbent for the purification of industrial effluents from lead and cadmium [9] compounds and a method for purifying wastewater from phosphorus compounds were developed [10]. The latter circumstance determined its selection as an object of comparison when assessing the efficiency of the process of dephosphorization of wastewater by the tested coagulants.

\section{Experimental}

Working solutions of iron (III) sulfate and aluminum sulfate were prepared by dissolving in water $\mathrm{Fe}_{2}\left(\mathrm{SO}_{4}\right)_{3} \cdot 9 \mathrm{H}_{2} \mathrm{O}$ (qualification "pure", GOST 9485-74) and $\mathrm{Al}_{2}\left(\mathrm{SO}_{4}\right)_{3} \cdot 18 \mathrm{H}_{2} \mathrm{O}$ (qualification “pure”, GOST 3758-75) respectively.

For the production of aluminum-silicate coagulant, it was used nepheline concentrate (NC) produced by OJSC «Apatit» (Kirovsk city, Murmansk Oblast), which is released during the processing of apatite-nepheline ore at concentration plants. The mineral nepheline, the amount of which in the composition of the NC is $80 \div 85 \%$, has several unique properties, such as the constancy of the chemical composition and the ability to decompose with almost all, even diluted, inorganic (and some organic) acids.

Decomposition of the nepheline concentrate was carried out by $12.5 \% \mathrm{H}_{2} \mathrm{SO}_{4}$ at a rate of $85 \%$ stoichiometry per $\Sigma\left(\left[\mathrm{Al}_{2} \mathrm{O}_{3}\right.\right.$ acid-soluble], [ $\left.\left.\mathrm{Na}_{2} \mathrm{O}\right],\left[\mathrm{K}_{2} \mathrm{O}\right]\right)$, where $\left[\mathrm{Al}_{2} \mathrm{O}_{3}\right.$ acid-soluble], [ $\left.\mathrm{Na}_{2} \mathrm{O}\right],\left[\mathrm{K}_{2} \mathrm{O}\right]$ - is the content of acid-soluble $\mathrm{Al}_{2} \mathrm{O}_{3}, \mathrm{Na}_{2} \mathrm{O}, \mathrm{K}_{2} \mathrm{O}$ in NC, respectively, for 15 minutes. According to the reaction (1), the final products of the interaction of nepheline 
with acid were salts of aluminum, alkaline elements and weakly dissociated orthosilicic acid $\mathrm{H}_{4} \mathrm{SiO}_{4}$.

$$
(\mathrm{Na}, \mathrm{K})_{2} \mathrm{O} \cdot \mathrm{Al}_{2} \mathrm{O}_{3} \cdot 2 \mathrm{SiO}_{2}+8 \mathrm{H}^{+} \rightarrow 2(\mathrm{Na}, \mathrm{K})^{+}+2 \mathrm{Al}^{3+}+2 \mathrm{H}_{4} \mathrm{SiO}_{4}
$$

At the end of the decomposition process, the resulting pulp was filtered to separate the insoluble residue, the solution was analyzed for its $\mathrm{Al}_{2} \mathrm{O}_{3}$ content, after which it was diluted to an operating concentration of $10 \mathrm{~g} / \mathrm{l}$ (by $\mathrm{Al}_{2} \mathrm{O}_{3}$ ).

Aluminum oxysulfate and oxychloride were prepared by dissolving active aluminum hydroxide in sulfuric or hydrochloric acid, which in turn was obtained by thoroughly mixing crystalline aluminum chloride $\left(\mathrm{AlCl}_{3} \cdot 6 \mathrm{H}_{2} \mathrm{O}\right)$ and anhydrous sodium carbonate $\left(\mathrm{Na}_{2} \mathrm{CO}_{3}\right)$ (both "chemically pure"), taken with $10 \%$ excess of the stoichiometrically necessary amount to form aluminum and sodium bicarbonate by reaction (2):

$$
\mathrm{AlCl}_{3} \cdot 6 \mathrm{H}_{2} \mathrm{O}_{(\mathrm{s})}+2 \mathrm{Na}_{2} \mathrm{CO}_{3(\mathrm{~s})} \rightarrow \mathrm{NaAl}(\mathrm{OH})_{2} \mathrm{CO}_{3}+3 \mathrm{NaCl}+\mathrm{CO}_{2} \uparrow+5 \mathrm{H}_{2} \mathrm{O}
$$

The reagents mixing process was carried out in a laboratory mixer-grinder "WARING" at room temperature, during which intensive $\mathrm{CO}_{2}$ release was observed, indicating the progress of the process, and the formation of a bulk-increasing dry friable mass. The completion of the reaction was indicated by the cessation of $\mathrm{CO}_{2}$ isolation. The resulting product was leached with water at $50{ }^{\circ} \mathrm{C}$ for 15 minutes at a ratio of $\mathrm{L}: \mathrm{S}=5: 1$, after which the precipitate was separated from the solution on a suction filter and washed on a filter to $\mathrm{pH} \approx 7$. During leaching and washing, the precipitate $\mathrm{NaAl}(\mathrm{OH})_{2} \mathrm{CO}_{3}$ was hydrolyzed by reaction (3): to form active aluminum hydroxide in the form of pseudobemite.

$$
2 \mathrm{NaAl}(\mathrm{OH})_{2} \mathrm{CO}_{3} \rightarrow \mathrm{Al}_{2} \mathrm{O}_{3} \cdot \mathrm{H}_{2} \mathrm{O}+\mathrm{Na}_{2} \mathrm{CO}_{3}+\mathrm{CO}_{2}+\mathrm{H}_{2} \mathrm{O}
$$

The obtained aluminum hydroxide was dissolved in a calculated amount of sulfuric or hydrochloric acid, the solutions were analyzed for the content of $\mathrm{Al}_{2} \mathrm{O}_{3}, \mathrm{Cl}^{-}$, or $\mathrm{SO}_{4}{ }^{2-}$, and then diluted to an working concentration of $\mathrm{Al}_{2} \mathrm{O}_{3}(10 \mathrm{~g} / \mathrm{l})$.

In Table 2 there are shown the characteristics of the working solutions of coagulants.

Table 2. Characteristics of working solutions of coagulants.

\begin{tabular}{|c|c|c|c|c|c|c|c|c|c|}
\hline \multirow{2}{*}{ Designation } & \multicolumn{9}{|c|}{ Characteristic } \\
\cline { 2 - 11 } & $\begin{array}{c}\mathrm{Fe}_{2} \mathrm{O}_{3}, \\
\mathrm{~g} / \mathrm{l}\end{array}$ & $\begin{array}{c}\mathrm{Al}_{2} \mathrm{O}_{3}, \\
\mathrm{~g} / \mathrm{l}\end{array}$ & $\begin{array}{c}\mathrm{SiO}_{2}, \\
\mathrm{~g} / \mathrm{l}\end{array}$ & $\begin{array}{c}\mathrm{Na}_{2} \mathrm{O}, \\
\mathrm{g} / \mathrm{l}\end{array}$ & $\begin{array}{c}\mathrm{K}_{2} \mathrm{O}, \\
\mathrm{g} / \mathrm{l}\end{array}$ & $\begin{array}{c}\mathrm{SO}_{4}^{2-}, \\
\mathrm{g} / \mathrm{l}\end{array}$ & $\begin{array}{c}\mathrm{Cl}^{-}, \\
\mathrm{g} / \mathrm{l}\end{array}$ & $\mathrm{pH}$ & $\begin{array}{c}\rho, \\
\mathrm{g} / \mathrm{cm}^{3}\end{array}$ \\
\hline \begin{tabular}{c} 
Ferric sulphate (SF) \\
\hline $\begin{array}{c}\text { Aluminium sulphate } \\
\text { (SA) }\end{array}$
\end{tabular} & - & 10 & - & - & - & 28 & - & 1.04 & 1.037 \\
\hline ASC (ASC) & $0.8-0.9$ & 10 & $13-14$ & $4.5-5.5$ & $2-2.5$ & $38-41$ & - & 3.06 & 1.063 \\
\hline $\begin{array}{c}\text { Aluminium } \\
\text { oxysulphate (OSA) } \\
\mathrm{Al}(\mathrm{OH})_{0.6}\left(\mathrm{SO}_{4}\right)_{1.2}\end{array}$ & - & 10 & - & 0.55 & & 25.6 & - & 3.91 & 1.027 \\
\hline $\begin{array}{c}\text { Aluminium } \\
\text { oxychloride (OXA) } \\
\mathrm{Al}(\mathrm{OH})_{2.25} \mathrm{Cl}_{0.75}\end{array}$ & - & 10 & - & 0.84 & - & - & 8.5 & 4.26 & 1.013 \\
\hline
\end{tabular}

White mud produced by the Bogoslovsk aluminum plant was provided for testing by LLC "Sorbent-K" (Yekaterinburg city). The product contained a sulphate form of a sodalite group aluminosilicate with a weight fraction of up to $90 \%$ - iron hydrogen garnet with weight fraction up to $15 \%$ and finely dispersed aluminum hydroxide with weight fraction up to $5 \%$. The chemical composition of WM is given in Table 3.

A sample of wastewater provided by JSC "Apatityvodokanal" with a phosphorus content of $1.8 \mathrm{mg} / \mathrm{l}$ (based on total P) was used as the object of investigation of coagulants and WM sorbent. 
Table 3. Chemical composition of white sludge produced by the Bogoslovsk aluminum plant [10].

\begin{tabular}{|l|c|}
\hline Designation of ingredient & Mass fraction, \% \\
\hline Alumina & $25-35$ \\
\hline Silica & $20-25$ \\
\hline Ferrous oxide & $3-10$ \\
\hline Calcium oxide & $3-10$ \\
\hline Sodium oxide & $15-20$ \\
\hline Sulfur oxide & $3-6$ \\
\hline Potassium oxide & $0.5-2.0$ \\
\hline Free alkali & not more than 0.02 \\
\hline Moisture content & not more than 15 \\
\hline
\end{tabular}

To carry out the test coagulation, wastewater was poured into the glasses, after which a calculated amount of coagulant solutions with a concentration of $10 \mathrm{mg} \mathrm{Al}_{2} \mathrm{O}_{3}$ /liter was introduced into it with vigorous stirring. In all tests, the $\mathrm{pH}$ of the purified water was adjusted to 8 before coagulation, which was ensured by its correction and control on an automatic potentiometric titrator ATП-02 $0.1 \mathrm{M}$ with a solution of $\mathrm{Na}_{2} \mathrm{CO}_{3}$.

The consumption of coagulants varied from 10 to $50 \mathrm{mg} \mathrm{Al}_{2} \mathrm{O}_{3} /$ liter of wastewater. After the introduction of the coagulant, the mixture was stirred for 2 minutes, and then stirrer was turned off, aluminum hydroxide flakes were settling out. The settling process was carried out for 60 minutes, after which the clarified part of the solutions was decanted, filtered, and analyzed for the residual phosphorus content in it. In the process of settling, the sedimentation rate of coagulation flocs and the final $\mathrm{pH}$ of the purified water were also determined.

Wastewater was purified from phosphorus using the WM sorbent at a flow rate of 0.5 to $5 \mathrm{~g} / \mathrm{l}$ of wastewater and a contact time of 4 and 7 hours. At the end of the sorption process, the pulp was settled, the clarified part of the solutions was drained by decantation, filtered and analyzed for its residual phosphorus content, and the final $\mathrm{pH}$ of the purified water was determined.

The residual phosphorus concentration was determined by inductively coupled plasma atomic emission spectrometry on Optima 8300.

\section{Results and discussion}

The experiment results are shown in Figures 1-5. The same efficiency of all types of coagulants was shown in Figure 1, fundamentally that was explained the different mechanisms of the purification process. Thus, if, in the case of cleaning water from suspended particles and metal ions, for example, $\mathrm{Cu}^{2+}$ or $\mathrm{Co}^{2+}$, they are sorbed on the surface of the resulting aluminum hydroxide flakes, followed by their co-precipitation and removal, then when water is purified from phosphorus, it is removed due to the formation of insoluble aluminum phosphate by the reaction (4).

$$
\mathrm{Al}^{3+}+\mathrm{PO}_{4}^{3-} \rightarrow \mathrm{AlPO}_{4} \downarrow
$$

It was also indicated by the fact that an increase in concentration coagulant of more than $10 \mathrm{mg} \mathrm{Al} \mathrm{O}_{3} /$ liter for ASC, OSA, and OXA, and $20 \mathrm{mg} \mathrm{Al} \mathrm{O}_{3} /$ liter for iron and aluminum sulphates does not lead to a decrease in the degree of purification, which may be due to the low but sufficient solubility of the $\mathrm{AlPO}_{4}$, which does not allow the water to be completely purified from phosphorus. However, it should be pointed out that the water to be purified had a low initial phosphorus content $(\approx 1.8 \mathrm{mg} / \mathrm{l})$ during tests. At its increasing, it will be required additional studies to adjust coagulant flow to achieve an acceptable degree of purification. 
The different results were observed when using the WM sorbent to remove phosphorus from water (figure 2). The nature of the linear dependencies were indicated the mechanism of phosphate ion sorption on the surface of WM particles, which, in turn, linearly depends on the amount of sorbent introduced into the water being purified. At the same time, considering the small difference between the residual phosphorus concentration and the sorption time at the same sorbent consumption, it can be assumed that the sorption process proceeds at a high rate and to increase the degree of purification it is more effective to increase the sorbent consumption than to increase the sorption time. However, it will lead to an increase in the amount of mud and, respectively, to an increase in the cost of its separation from water and disposal.

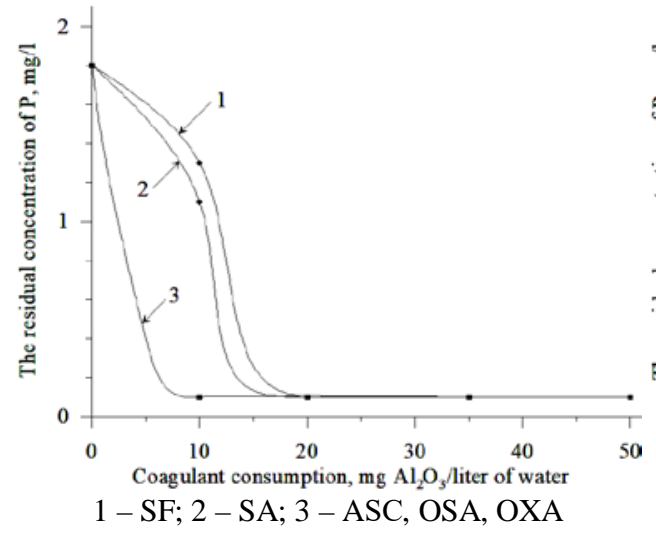

Fig. 1. Influence of the consumption of coagulants on the residual concentration of phosphorus

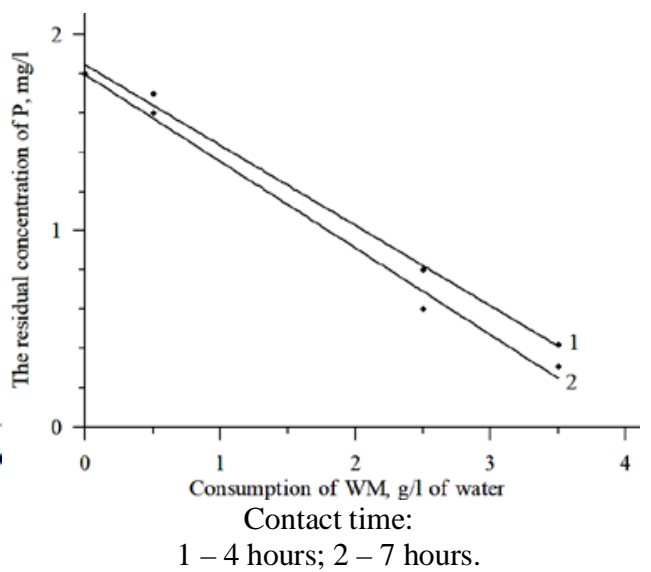

Fig. 2. Influence of $\mathrm{WM}$ consumption and contact time on the residual phosphorus concentration

The dependences of the residual concentration of phosphorus $\left(\mathrm{C}_{\mathrm{P}}, \mathrm{mg} / \mathrm{l}\right)$ on the $\mathrm{WM}$ consumption ( $\mathrm{G}, \mathrm{g} / \mathrm{l}$ of water) are satisfactorily described by the following equations:

- for a contact time of 4 hours: $C_{P}=1.845-0.409 \cdot G$;

- for a contact time of 7 hours: $C_{P}=1.796-0.442 \cdot G$.

The results data on the influence of the flow rate and the type of coagulants on the final $\mathrm{pH}$ value of purified water was shown in figure 3. As expected, when using aluminum oxychloride, the lower value $\mathrm{pH}$ of purified water was observed, which has the highest basicity than other coagulants.

The dependences of the final $\mathrm{pH}$ value on the flow rate of concentration of coagulants ( $\mathrm{G}, \mathrm{g} \mathrm{Al}_{2} \mathrm{O}_{3}$ /liter of water) were satisfactorily described by the following equations:

- for iron (III) sulfate: $\mathrm{pH}=8.030-0.019 \cdot \mathrm{G}$;

- for aluminum sulfate: $\mathrm{pH}=8.021-0.031 \cdot \mathrm{G}$;

- for aluminosilicate coagulant: $\mathrm{pH}=8.075-0.050 \cdot \mathrm{G}$;

- for aluminum oxysulfate: $\mathrm{pH}=8.010-0.023 \cdot \mathrm{G}$;

- for aluminum oxychloride: $\mathrm{pH}=8.010-0.013 \cdot \mathrm{G}$.

White mud has the opposite influence due to its nature, it has alkaline properties, consequently, the $\mathrm{pH}$ of the purified water rises during its use (figure 4). Although, in this case, the effect of the WM consumption is more significant than the effect of the time of its contact with water, which indicates a high rate of desorption of $\mathrm{OH}$ - ions from its surface into the water volume, as a result of which the acid-base equilibrium is achieved relatively quickly. 


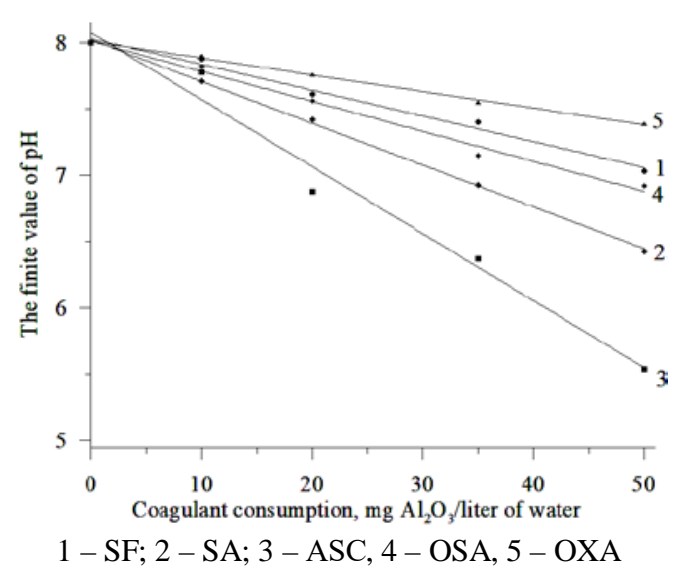

Fig. 3. Influence of the consumption of coagulants on the final $\mathrm{pH}$ value of water

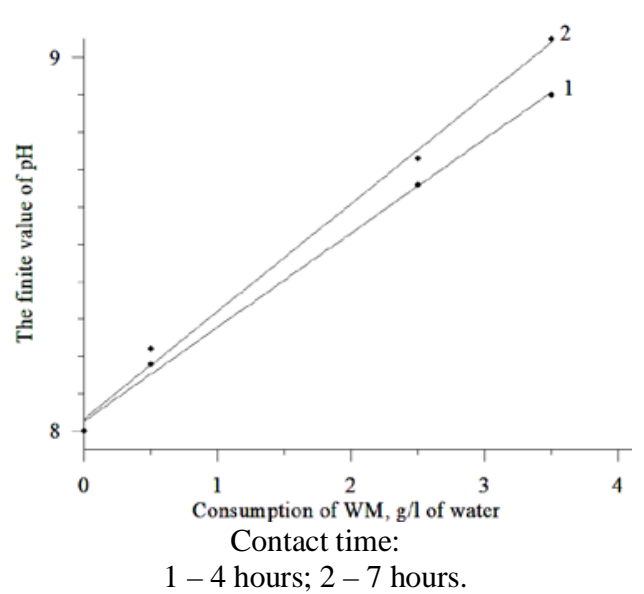

Fig. 4. Influence of WM consumption and contact time on the final $\mathrm{pH}$ value of water

The dependences of the final $\mathrm{pH}$ value on the WM flow rate $(\mathrm{G}, \mathrm{g} / \mathrm{l}$ of water) were satisfactorily described by the following equations:

- for a contact time of 4 hours: $\mathrm{pH}=8.026+0.252 \cdot \mathrm{G}$;

- for a contact time of 7 hours: $\mathrm{pH}=8.032+0.288 \cdot \mathrm{G}$.

Research data on the effect of the consumption of coagulants on the sedimentation rate of coagulation flakes were shown in figure 5. As shown in figure, at low flow rates (less than $10 \mathrm{mg} \mathrm{Al}_{2} \mathrm{O}_{3} /$ liter of purified water for aluminum oxychlorides and oxysulfates and less than $20 \mathrm{mg} \mathrm{Al}_{2} \mathrm{O}_{3}$ /liter of purified water for aluminum iron sulfates), the deposition rate is low, which can be explained by the small amount of formed hydroxide particles, which significantly complicates the process of their aggregation, which contributes to the deposition of particles. With increasing of the coagulants consumption the amount of formed particles increases. This facilitates their aggregation with the formation of large agglomerates, the deposition rate of which is significantly higher. Further increase in the consumption of coagulants (more than $30 \mathrm{mg} \mathrm{Al} \mathrm{A}_{2} \mathrm{O}_{3}$ /liter of purified water for aluminum oxychlorides and oxysulfates and more than $40 \mathrm{mg} \mathrm{Al} \mathrm{AO}_{3}$ /liter of purified water for iron and aluminum sulfates) leads to the formation of an excessively large amount of large agglomerates (flakes) of particles, which, in its turn, interferes with the process of their deposition due to its constraint, reducing the rate of deposition of particles.

Moreover, it should be noted that the maximum deposition rate for aluminum oxychloride and oxysulfate is achieved at their consumption of $\approx 30 \mathrm{mg} \mathrm{Al} \mathrm{O}_{3}$ /liter of water being purified, while for iron and aluminum sulfates, the maximum deposition rate requires an increase in their consumption to $40 \mathrm{mg} \mathrm{Al}_{2} \mathrm{O}_{3}$ /liter of purified water. This proves that the use of oxychloride and aluminum oxysulfate produces larger and accordingly heavier coagulation flakes whose deposition rate is higher.

The intermediate value was occupied by aluminosilicate coagulant because it contains both aluminum sulfate and dissolved silica $\left(\mathrm{SiO}_{2}\right)$, which plays the role of a flocculant and contributes to the formation of large coagulation flakes. This is probably explained by the fact that the maximum deposition rate of coagulation flakes is achieved at a lower coagulant flow rate $\left(\approx 30 \mathrm{mg} \mathrm{Al}_{2} \mathrm{O}_{3} /\right.$ liter $)$ than iron and aluminum sulphates, while increasing their deposition rate. 


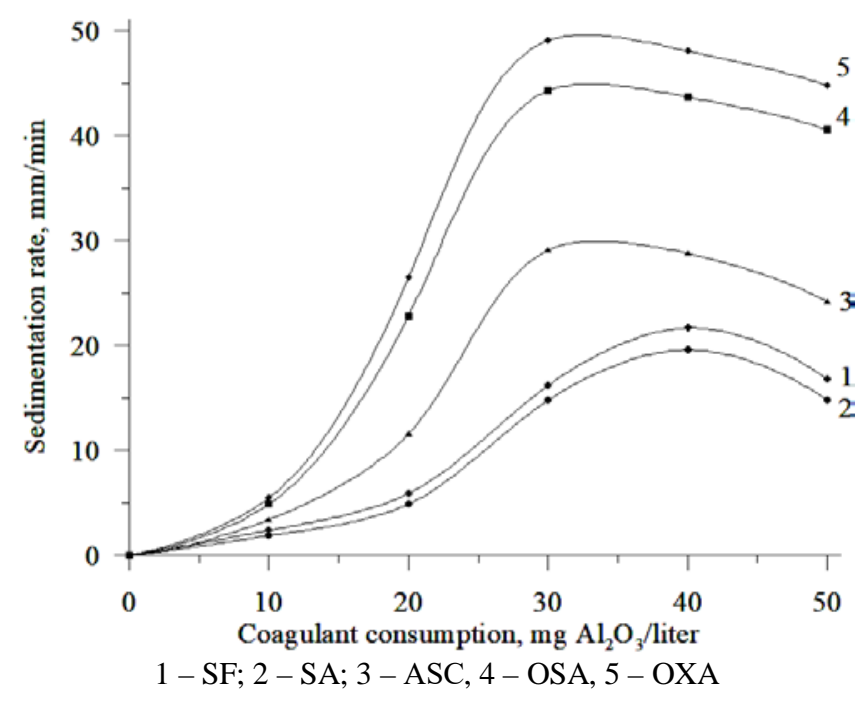

Fig. 5. Influence of the consumption of coagulants on the sedimentation rate of coagulation flakes

\section{Conclusions}

The process of dephosphotation of municipal wastewater was carried out. It was found that all aluminum and iron-containing coagulants are suitable for purifying wastewater from phosphorus. In this case, the best results in terms of efficiency (degree of purification, final $\mathrm{pH}$ value of purified water, rate of precipitation of coagulation flakes) were obtained for a coagulant based on aluminum oxychloride.

\section{References}

1. I.A. Terenteva, N.A. Kashulin, D.B. Denisov Ocenka troficheskogo statusa subarkticheskogo ozera Imandra [Taxation of the trophic status of the subarctic lake Imandra], Bulletin of Murmansk technical University, 20, 1-2, pp. 197-204, (2017), (in Russian).

2. V.V. Bulion Novyj vzglyad na paradigmu fosfornogo kontrolya v limnologii [A new look at the paradigm of phosphorus control in limnology], Advances of modern biology, 136, 3, pp. 311-318, (2016) (in Russian).

3. D.A. Danilovich, A.N. Epov, M.A. Kanunnikova Analiz dannyh raboty ochistnyh sooruzhenij rossijskih gorodov - osnova dlya tekhnologicheskogo normirovaniya [Analysis of data on the operation of treatment facilities in Russian cities - the basis for technological normalization], Best available water supply and sanitation technologies, 3-4, pp. 18-28 (2015) (in Russian).

4. Yu.M. Meshengisser Retekhnologizaciya sooruzhenij ochistki stochnyh vod [Retechnologization of wastewater treatment facilities] (LLC "Publishing House" Around the color", Moscow, 208 p., 2012) (in Russian).

5. Metodika razrabotki reestra nailuchshih dostupnyh tekhnologij (NTD) sistem vodosnabzheniya $i$ vodootvedeniya. Razdel 2. Kanalizaciya. T.1. [Methodology for developing the register of best available technologies (NTD) for water supply and sanitation systems. Section 2. Sewerage. T.1.] (National Association of designers, Moscow, 141 p., 2014) (in Russian). 
6. ITS 10-2015. Ochistka stochnyh vod s ispol'zovaniem centralizovannyh sistem vodootvedeniya poselenij, gorodskih okrugov [Wastewater treatment using centralized water disposal systems in settlements and urban districts], (Bureau of NTD, Moscow, 377 p., 2015) (in Russian).

7. Patent № RU 2053688.

8. Patent № RU 2036844.

9. Patent RU 2412756.

10. Patent RU 2440304.

11. D. Dihang, P. Aimar, J. Kayema, S.N. Koungou Coagulation and flocculation of laterite suspensions with low levels of aluminium chloride and polyacrylamids, Chemical Engineering and Processing, 47, 1509-1519 (2008).

12. M. Kimura, Y. Matsui, K. Kondo, T.B. Ishikawa, T. Matsushita, N. Shirasaki Minimizing residual aluminum concentration in treated water by tailoring properties of polyaluminum coagulants, Water research, 47, 2075-2084 (2013).

13. F. Nyström, K. Nordqvist, I. Herrmann, A. Hedström, M. Viklander Removal of metals and hydrocarbons from stormwater using coagulation and flocculation, Water Research, 182, 115919 (2020).

14. K. Rajala, O. Grönfors, M. Hesampour, A. Mikola Removal of microplastics from secondary wastewater treatment plant effluent by coagulation/flocculation with iron, aluminum and polyamine-based chemicals, Water Research, 116045 (2020).

15. A.K. Tolkou, M. Mitrakas, I.A. Katsoyiannis, M. Ernst, A.I. Zouboulis Fluoride removal from water by composite $\mathrm{Al} / \mathrm{Fe} / \mathrm{Si} / \mathrm{Mg}$ prepolymerized coagulants: Characterization and application, Chemosphere, 231, 528-537 (2019).

16. Y. Suna, C. Zhua, H. Zhengc, W. Suna, Y. Xub, X. Xiaob, Z. Youa, C. Liu Characterization and coagulation behavior ofpolymeric aluminum ferric silicate forhigh-concentration oily wastewater treatment, Chemical engineering research and design, 119, 23-32 (2017).

17. S. Ghafari, H.A. Aziz, M.H. Isa, A.A. Zinatizadeh Application of response surface methodology (RSM) to optimize coagulation-flocculation treatment of leachate using poly-aluminum chloride (PAC) and alum, Journal of Hazardous Materials, 163, 650-656 (2009).

18. W.L. Ang, A.W. Mohammad State of the art and sustainability of natural coagulants in water and wastewater treatment, Journal of Cleaner Production, 262, 121267 (2020).

19. G. Zhua, H. Zhenga, Z. Zhanga, T. Tshukudua, P. Zhanga, X. Xiang Characterization and coagulation-flocculation behavior of polymeric aluminum ferric sulfate (PAFS), Chemical Engineering Journal, 178, 50-59 (2011).

20. F.M. Mohamed, K.A. Alfalous The effectiveness of activated silica derived from rice husk in coagulation process compared with inorganic coagulants for wastewater treatment, Egyptian Journal of Aquatic Research, 46, 131-136 (2020).

21. A. Nath, A. Mishra, P.P. Pande A review natural polymeric coagulants in wastewater treatment, Materials Today: Proceedings, (2020).

22. Y.O. Velyaev, V.I. Zakharov, D.V. Maiorov Improvement of the technology for the synthesis of an alumosilicate coagulant-flocculant based on nepheline, Glass Physics and Chemistry, 37, 5, 568-571 (2011). 